\title{
Gonadal impairment in roach Rutilus rutilus from Finnish coastal areas of the northern Baltic Sea
}

\author{
Tom Wiklund ${ }^{1, *}$, Laura Lounasheimo ${ }^{1}$, Jiří Lom ${ }^{2}$, Göran Bylund ${ }^{1}$ \\ ${ }^{1}$ Institute of Parasitology, Åbo Akademi University, BioCity, Artillerigatan 6, FIN-20520 Åbo, Finland \\ ${ }^{2}$ Academy of Sciences of the Czech Republic, Institute of Parasitology, 37005 Ceské Budejovice, Branisovska 31, Czech Republic
}

\begin{abstract}
Gonadal impairment in roach Rutilus rutilus from Finnish coastal waters was studied during 1987-1995. The disease was observed in high prevalence $1>10 \%$, for roach in length class $25-30 \mathrm{~cm}$ ) in roach from 4 sites in the Archipelago Sea, from one site influenced by cooling water discharge from a nuclear power plant in Gulf of Bothnia, and in roach from one site close to a metal processing plant in the northern Gulf of Bothnia. The sites in the Archipelago Sea were not directly affected by industrial pollution. The disease was most prevalent in large (old) female roach, and it was characterized by degeneration of the ovaries ranging from weak tissue changes in one ovary to complete absence or destruction of both ovaries. Oocytes, in affected gonads, were frequently infected by a microsporidian parasite Pleistophora mirandellae. In males atretic testes were never observed and only small cysts, containing $P$. mirandellae, were detected. In several affected roach, both male and female reproductive tissues were observed. The observed pathological changes in the ovaries of roach are suggested to be caused by $P$. mirandellae.
\end{abstract}

KEY WORDS: Roach - Rutilus rutilus - Baltic Sea - Reproductive failure - Microsporidia Pleistophora mirandellae Hermaphroditism

\section{INTRODUCTION}

Reproductive disorders have been reported to occur in several fish species in different areas of the Baltic Sea. Affected fish species include Atlantic salmon Salmo salar (Norrgren et al. 1993, Bylund \& Lerche 1995), burbot Lota lota (Segerstråle 1945, Pulliainen et al. 1992), cod Gadus morhua (Westernhagen et al. 1988, Larsson 1994), flounder Platichthys flesus (Westernhagen et al. 1981), herring Clupea harengus (Hansen et al. 1985), roach Rutilus rutilus, perch Perca fluviatilis, dace Leuciscus leuciscus and pike Esox lucius (Sandström et al. 1988, Karås et al. 1991, Pulliainen et al. 1992, Luksiene \& Sandström 1994, Wiklund \& Bylund 1994, Pekkarinen 1995). Reproduction disorders in different fish species have also been observed in other sea areas such as the North Sea (Westernhagen et al. 1989), Pacific Ocean (Hunter \& Macewicz 1985, Spies \& Rice 1988), Atlantic Ocean (Longwell et

•E-mail: twiklund@aton.abo.fi al. 1992, Johnson et al. 1994) and in freshwater areas (Norrgren et al. 1994, Fisher et al. 1995).

A common etiology for the reproduction disorders observed in different fish species has not been established, and different factors like organic contaminants (Westernhagen et al. 1981, Hansen et al. 1985), pulp mill effluents (Sandström et al. 1988, Karås et al. 1991), cooling water discharge (Luksiene \& Sandström 1994), parasite infections (Pedersen 1993, Pedersen et al. 1993, Pekkarinen 1995), and vitamin deficiency (Bylund \& Lerche 1995) have been associated with impaired production of viable offspring. On the other hand, contaminant exposure and increased levels of polychlorinated biphenyls (PCBs) in ovaries of spawning female English sole Parophrys vetulus were not associated with reduced reproductive success (Collier et al. 1992).

Distinct pathological changes or poor development of the gonads have previously been reported to affect roach (Pulliainen et al. 1992, Luksiene \& Sandström 1994, Wiklund \& Bylund 1994, Pekkarinen 1995), pike and burbot (Pulliainen et al. 1992) populations in certain areas of the Baltic Sea. 
In the present study we report the occurrence of ovary degeneration in roach from Finnish coastal waters of the northern Baltic Sea. The observed pathological changes are suggested to be associated with an infection by a microsporidian parasite, Pleistophora mirandellae Vaney \& Conte (Vaney \& Conte 1901).

\section{MATERIALS AND METHODS}

Sampling area. Roach was included in a study of diseases in different fish species in Finnish coastal waters in the northern Baltic Sea during 1987-1990 and 1994-1995 (Fig. 1). The water salinity in the investigated areas varies between 2 and $6 \%$ with the highest salinity in the Archipelago Sca and the lowest in the eastern Gulf of Finland and the northern Bothnian Bay (Fig. 1). The temperature of the surface water varies from $0^{\circ} \mathrm{C}$ in winter up to $20^{\circ} \mathrm{C}$ in summer. Most parts

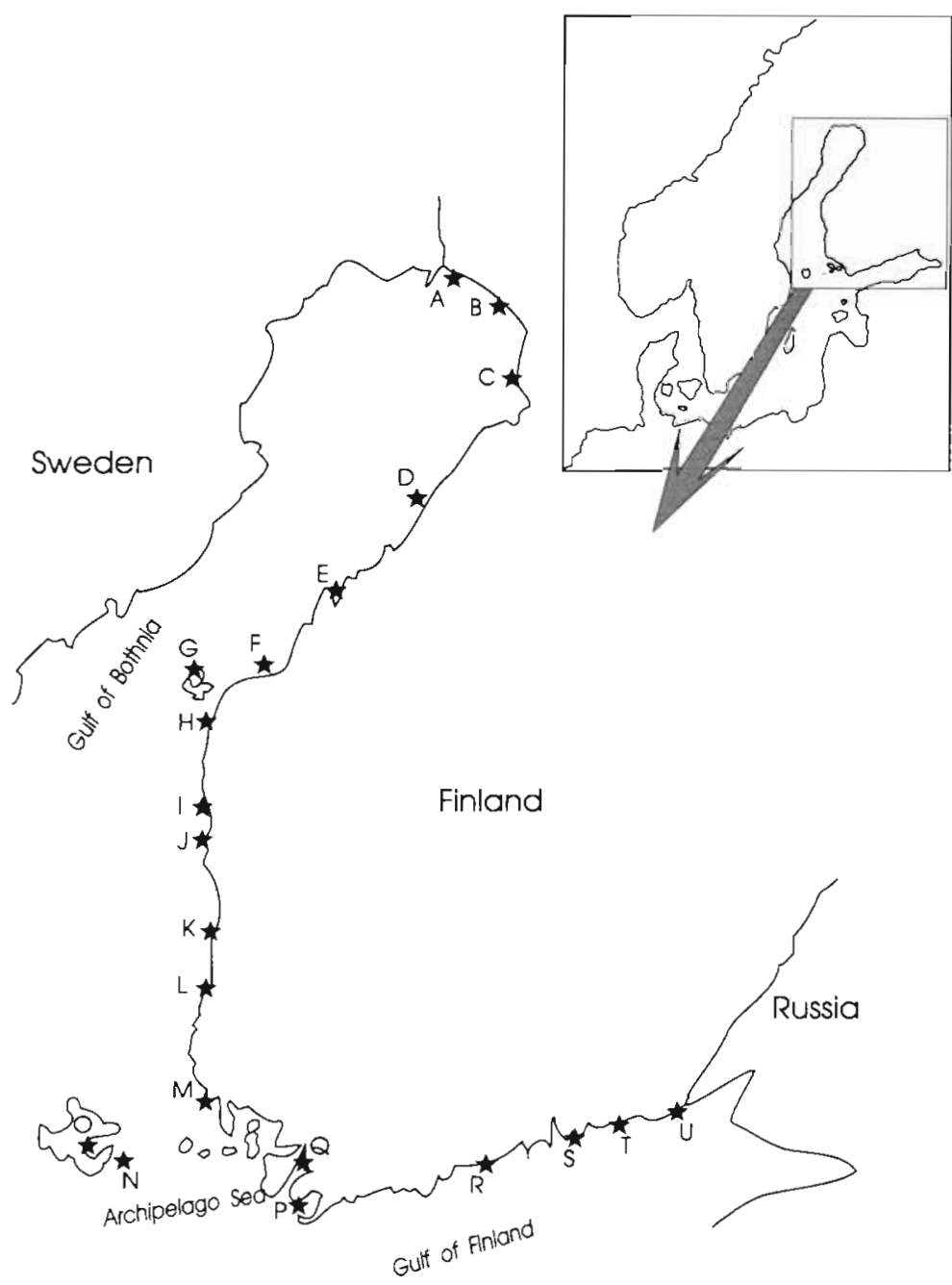

Fig. 1 Sampling sites of roach Rutilus rutilus in Finnish coastal areas of the northern Baltic Sea of the sampling sites are normally covered with ice between December and April. The northern Baltic Sea is generally considered polluted and most sampling sites were affected by eutrophication. Sites A, C, I, K and $\mathrm{T}$ (Fig. 1) were influenced by effluents in different degrees from various industries and sewage from nearby cities. Site L was affected by cooling water from a nuclear power plant.

For comparison, roach samples were taken from fresh water from Lake Pyhäjärvi in SW Finland.

Fish sampling. The samples were collected from commercial fish catches during spring and autumn. The roach were caught close to the shore with standing gill nets and bow nets and transported to a laboratory for examination. The roach were examined for lesions and disedse syinpioms in the gonads. Ail issh were sexed, and length and weight were determined.

Histological sampling and examination. Both affected and normal gonad tissue were sampled for histological examination as soon as possible after catching. The samples were preserved in Bouin's fluid or phosphate buffered formalin (4\%), processed for light microscopy, sectioned $(6 \mu \mathrm{m})$ and stained with Hematoxylin \& Eosin or Heidenhain's Azan according to standard procedures.

Oocyte development was estimated according to the method of Jafri (1990).

Analysis of data. The fish specimens were divided into 4 length classes $(<20 \mathrm{~cm}$, $20.1-25.0 \mathrm{~cm}, 25.1-30.0 \mathrm{~cm},>30.0 \mathrm{~cm}$ ) for analysis of disease prevalences in the different length classes. The roach from site $N$ were also divided into length classes of $1 \mathrm{~cm}$ for a detailed analysis of disease prevalences. The temporal variation in disease prevalences between different years were estimated for roach from 2 sites: 1 with high (site N), and 1 with low (site U) disease prevalence observed during the first sampling year.

\section{RESULTS}

\section{Macroscopic description of the affected gonads}

The color of the affected ovary in roach varied from white to red and dark brown. The degree of abnormality in the females varied considerably from minimal, light tissue changes to complete absence or destruction of both ovaries (Fig. 2). Affected ovaries were often infiltrated with areas of opaque, 
grayish to pink or dark red tissue. The size of the affected ovary was most often reduced. However, if one of the ovaries was absent or significantly reduced, the size of the other one was in some cases considerably increased. In males atretic testes were never observed, but large roach rather frequently developed both male and female genital products in the same gonad (Fig. 3).

\section{Microscopic description of affected gonads}

The disease affecting the roach ovaries was characterized by asynchronous oocyte development, oocyte atresia and serious degeneration of the gonad tissue in one or both ovaries (Figs. 4 \& 5).

Histologically, the affected ovaries were roughly divided into 2 distinct categories. The most frequently occurring of the 2 categories consisted of atretic tissue with more or less degenerated oocytes in various, often late (stage III-IV) developmental stages (Fig. 4). Many of these oocytes were infected with microsporidian meronts or spores which were identified as Pleistophora mirandellae. The infection was initiated by meronts appearing in II-IV stage oocytes. Gradually, the structure of the clearly defined oocyte wall broke down from the inside outwards under simultaneous invasion of macrophages. In some cases the wall of oocytes filled with spores retained its structure quite well, exhibiting only slight thinning and folding. Most often, however, the remnants of sporophorous oocytes were surrounded by a thick follicle of macrophages and epithelioid cells. The space between affected oocytes consisted of a massive stroma made of large secondary melanomacrophage centra, macrophages, inflammatory cells, erythrocytes, and sparse strains of connective tissue (Fig. 5). The final stage of the oocyte degeneration was a chronic granuloma. Large sections of the ovaries were affected, rather than
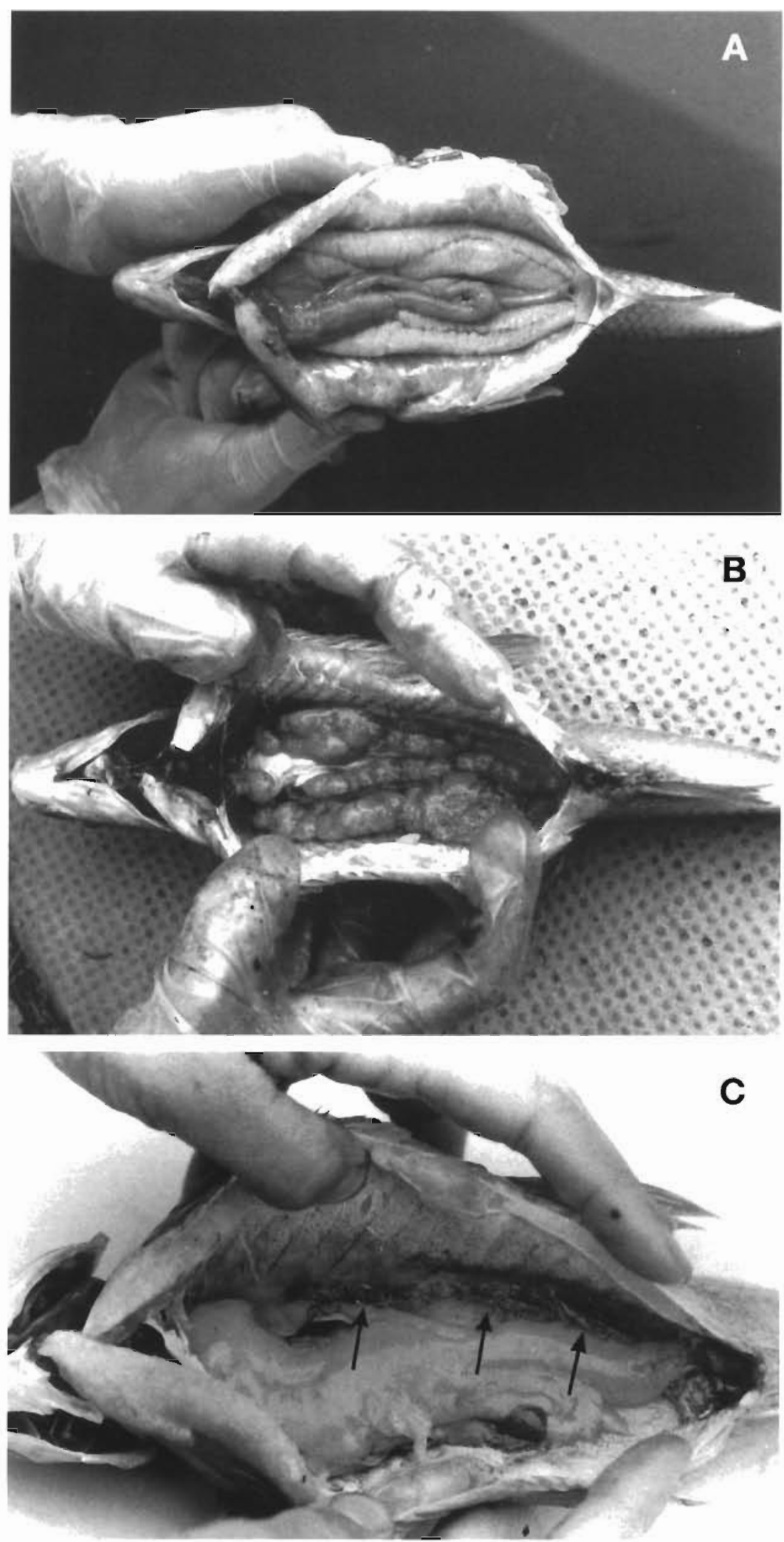

Fig. 2. Rutilus rutilus. Roach with (A) normally developed ovaries, (B) light changes in the ovary tissue, and (C, arrows) severe destruction of the ovary tissue 


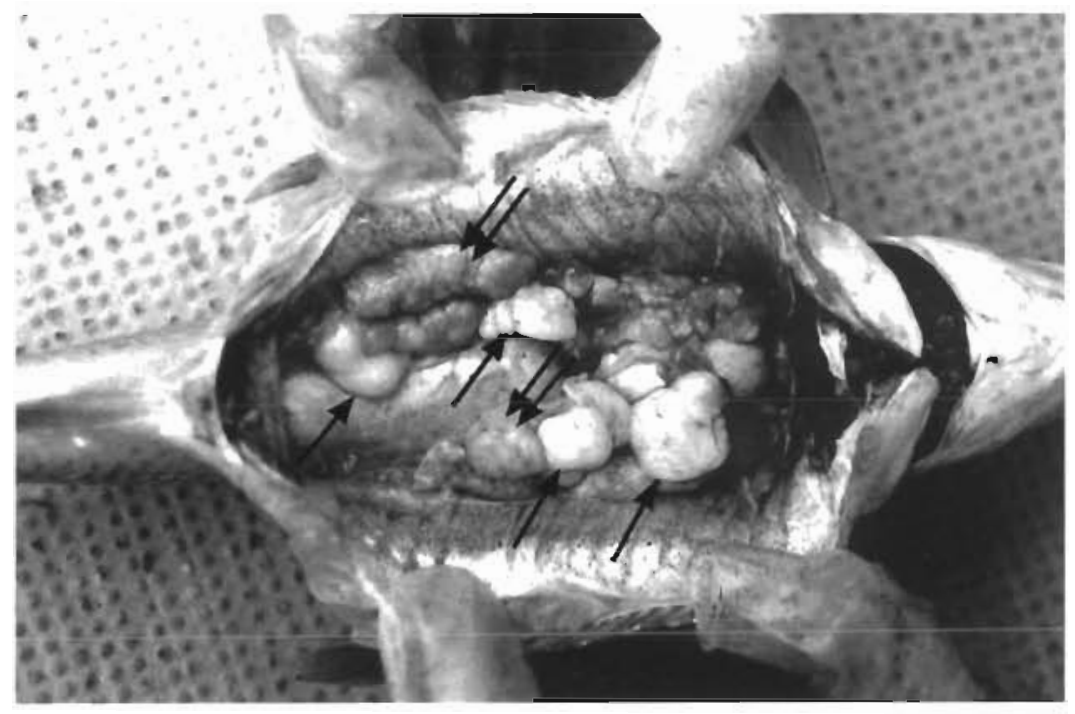

Fig. 3. Rutilus rutilus. Hermaphrodite roach with male (single arrow) and female (double arrow) reproductive tissue

Fig. 4. Rutilus rutilus. Overview of heavily affected ovarian tissue. Infected oocytes (arrows) are surrounded by large aggregates of inflammatory cells (C) and oocytes in developmental stage II (2) and stage III (3). Scale bar $=200 \mu \mathrm{m}$

Fig. 5. Rutilus rutilus. Oocyte $(O)$ in developmental stage IV filled with spores of Pleistophora mirandellae and surrounded by a mass of macrophages and other inflammatory cells. The oocyte wall (arrow) is in a state of disintegration. Scale bar $=50 \mu \mathrm{m}$
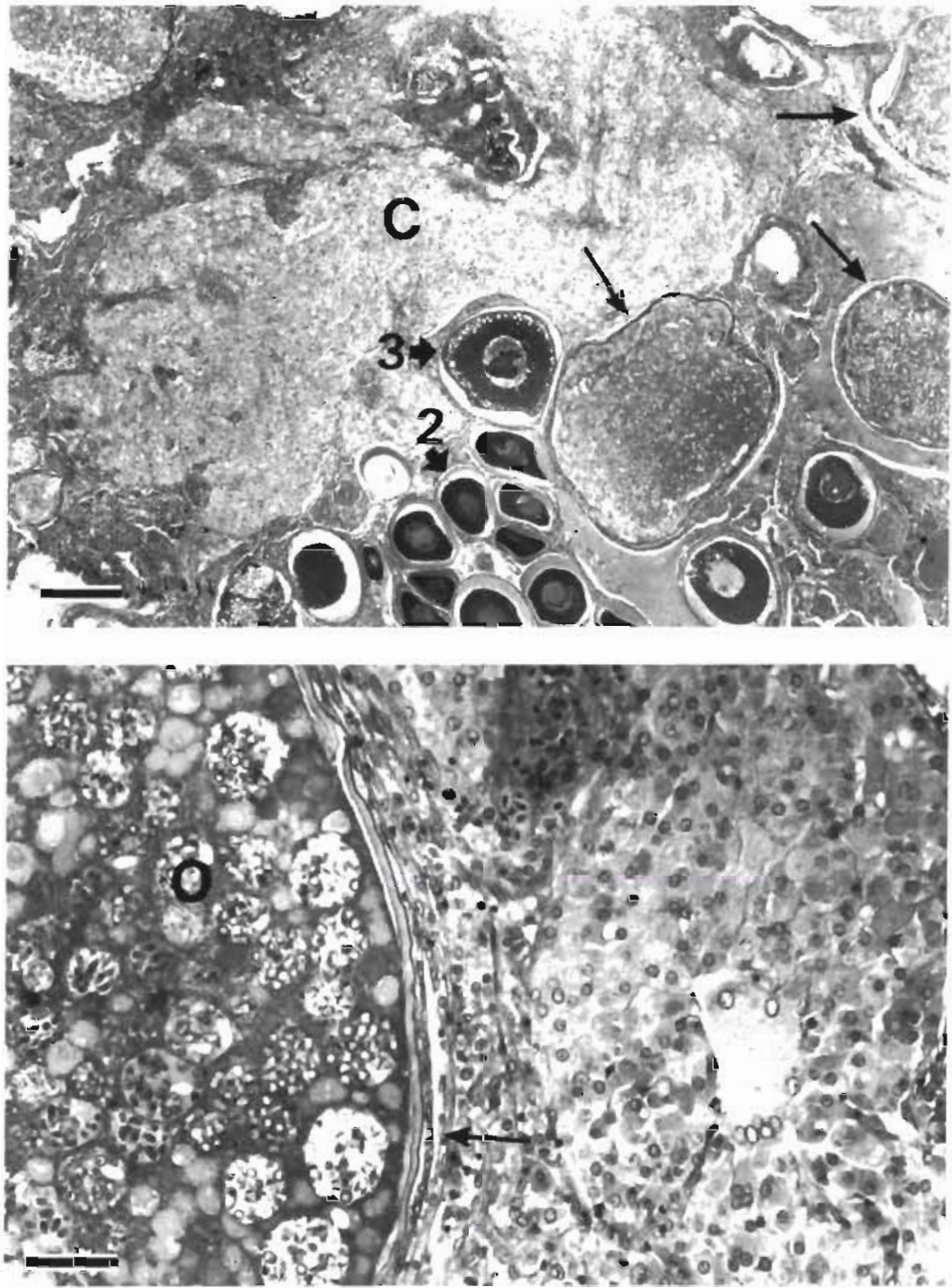


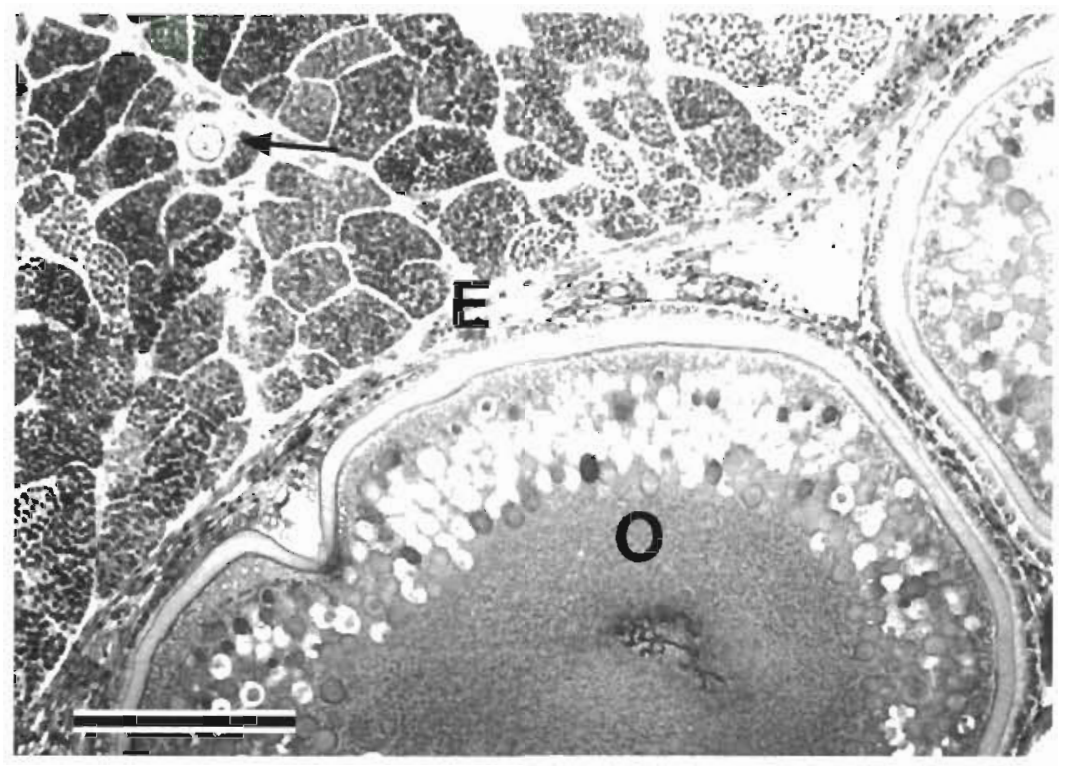

Fig. 6. Rutilus rutilus. Gonad tissue from a hermaphrodite roach. Oocyte in developmental stage IV $(O)$ is separated from spermatocysts by a narrow zone of epithelioid cells (E). One oocyte in developmental stage II (arrow) is completely surrounded by developing sperm tissue. Scale bar $=50 \mu \mathrm{m}$
The male roach were affected by Pleistophora mirandellae only insofar as some specimens exhibited small cysts in one or both testes (Fig. 7) These cysts contained spores of the parasite enclosed in a thin capsule and were often surrounded by a relatively narrow zone of inflammatory cells. No free spores or destruction of the affected testes were observed

\section{Spatial distribution of affected roach}

A total of 5983 roach from 21 different sites were examined (Fig. 1, Table 1). Roach with affected ovaries were found at most sampling sites (17 out of 21 sites) (Table 1 ). The most conclusive results with respect to the comparison of the disease prevalence between different sites were obtained from the length classes $20-25 \mathrm{~cm}$ and $25-30 \mathrm{~cm}$, although the number of individual oocytes. Oocytes without visible signs of infection were also frequently attacked by inflammatory cells and some of these oocytes were undergoing atresia

A second category of affected gonads included cases where the gonads carried both oocytes and spermatocytes, partially or totally mixed, in one or both gonads (Fig. 6). The male and female reproductive tissue was, however, mainly concentrated into separate regions of the gonads. Oocytes infected with Pleistophora mirandellae frequently occurred in areas containing only aocytes. In these areas the oocytes had usually reached a later developmental stage (stage III-IV). The spermatocytes did not appear to be susceptible to microsporidian infection. In hermaphrodite specimens, spores were not detected in oocytes that were interspersed in the spermatogenic tissue. These oocytes were characteristically in the early stages (stage I-II) of development regardless of the season.

Hard, tumour-like tissue without visible genital cells was present in the avaries of some of the affected roach. The tumour-like tissue consisted of a stroma of inflammatory cells and melanomacrophages, interlaced with strains of swirly connective tissue.

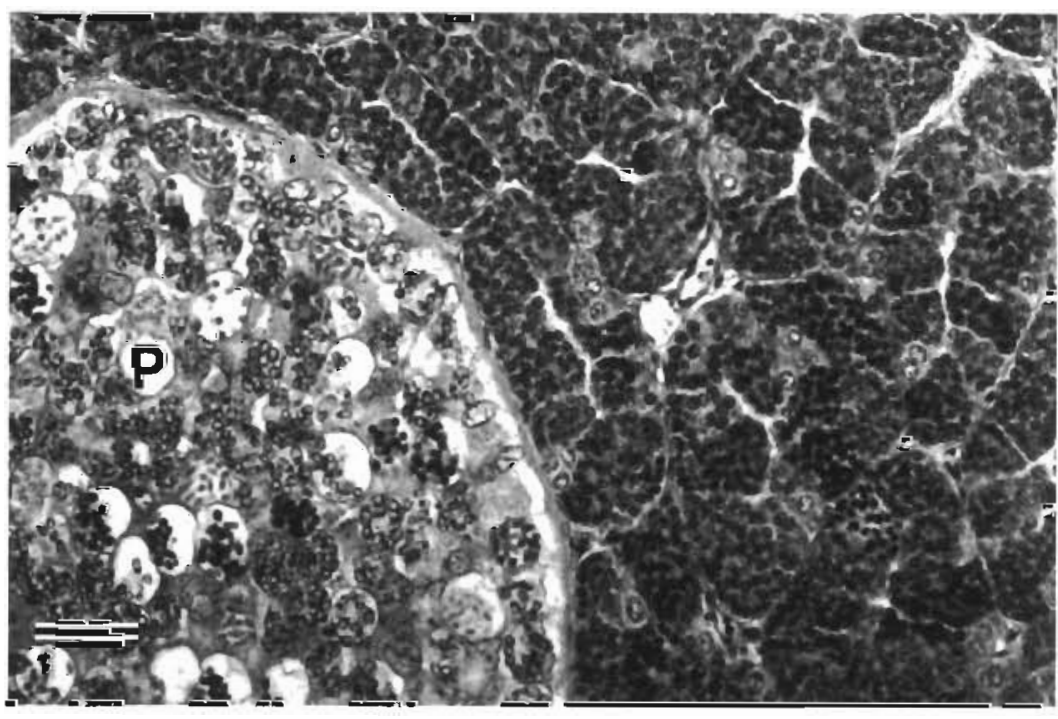

Fig. 7. Rutilus rutilus. Gonad tissue from affected male roach. A clearly defined parasite cyst $(\mathrm{P})$ containing spores of Pleistophora mirandellae is surrounded by normal spermatocytes. Scale bar $=50 \mu \mathrm{m}$ 
Table 1. Rutilus rutilus. Prevalence of roach affected by gonad impairment in different length classes at each site examined

\begin{tabular}{|c|c|c|c|c|c|c|c|c|c|c|c|}
\hline \multirow[t]{2}{*}{ Site } & \multirow[t]{2}{*}{ Site name } & \multirow{2}{*}{$\begin{array}{c}\text { Year } \\
\text { examined }\end{array}$} & \multirow{2}{*}{$\begin{array}{l}\text { Total } \\
\text { no. of } \\
\text { fish } \\
\text { examined }\end{array}$} & \multicolumn{2}{|c|}{$<20 \mathrm{~cm}$} & \multicolumn{2}{|c|}{$20-25 \mathrm{~cm}$} & \multicolumn{2}{|c|}{$25-30 \mathrm{~cm}$} & \multicolumn{2}{|c|}{$>30 \mathrm{~cm}$} \\
\hline & & & & $\begin{array}{l}\text { No. of } \\
\text { fish } \\
\text { examined }\end{array}$ & $\begin{array}{c}\text { Disease } \\
\text { prevalence } \\
(\%)\end{array}$ & $\begin{array}{l}\text { No. of } \\
\text { fish } \\
\text { examined }\end{array}$ & $\begin{array}{l}\text { Disease } \\
\text { prevalence } \\
(\%)\end{array}$ & $\begin{array}{l}\text { No. of } \\
\text { fish } \\
\text { examined }\end{array}$ & $\begin{array}{c}\text { Disease } \\
\text { prevalence } \\
(\%)\end{array}$ & $\begin{array}{l}\text { No. of } \\
\text { fish } \\
\text { examined }\end{array}$ & $\begin{array}{c}\text { Disease } \\
\text { prevalence } \\
(\%)\end{array}$ \\
\hline A & Torneá & 1989 & 160 & 6 & 0.0 & 30 & 3.3 & 114 & 15.0 & 10 & 30.0 \\
\hline $\mathrm{B}$ & Simo & 1989 & 143 & 0 & - & 59 & 1.7 & 78 & 3.8 & 6 & 16.7 \\
\hline $\mathrm{C}$ & Oulu & 1989 & 56 & 26 & 0.0 & 22 & 0.0 & 8 & 0.0 & 0 & - \\
\hline D & Kalajoki & 1989 & 491 & 43 & 0.0 & 411 & 4.1 & 37 & 5.4 & 0 & - \\
\hline E & Öja & 1989 & 66 & 59 & 0.0 & 6 & 0.0 & 1 & 0.0 & 0 & - \\
\hline $\mathrm{F}$ & Maxmo & $1988 / 90$ & 449 & 59 & 0.0 & 314 & 1.6 & 75 & 0.0 & 1 & 0.0 \\
\hline G & Björkö & 1989 & 95 & 0 & - & 46 & 2.2 & 49 & 4.1 & 0 & - \\
\hline $\mathrm{H}$ & Malax & 1988 & 407 & 10 & 0.0 & 266 & 0.4 & 128 & 3.9 & 3 & 33.3 \\
\hline I & Kaskö & 1988 & 49 & 0 & - & 2 & 0.0 & 47 & 6.4 & 0 & - \\
\hline J & Härkmeri & 1988 & 137 & 0 & - & 8 & 0.0 & 124 & 6.5 & 5 & 20.0 \\
\hline $\mathrm{K}$ & Pori & $1988 / 90$ & 397 & 36 & 0.0 & 196 & 5.1 & 157 & 4.5 & 8 & 0.0 \\
\hline L & Olkiluoto & 1988 & 20 & 0 & - & 0 & - & 14 & 21.0 & 6 & 100.0 \\
\hline$M$ & Taivassalo & 1988 & 357 & 16 & 0.0 & 88 & $i . i$ & 251 & 11.0 & 2 & 50.0 \\
\hline $\mathrm{N}$ & Föglö $\quad 1 s$ & $1988 / 90 / 94 / 95$ & $5 \quad 1965$ & 283 & 9.0 & 361 & 11.6 & 657 & 39.0 & 664 & 65.1 \\
\hline 0 & Ämnäs & 1988 & 354 & 1 & 100.0 & 56 & 7.1 & 272 & 37.0 & 25 & 72.0 \\
\hline$P$ & Bromarv & 1987 & 113 & 0 & - & 0 & - & 82 & 24.0 & 31 & 48.4 \\
\hline$Q$ & Kimito & 1987 & 72 & 1 & 0.0 & 0 & .- & 61 & 1.6 & 10 & 0.0 \\
\hline $\mathrm{R}$ & Helsingfors & 1987 & 13 & 9 & 0.0 & 2 & 0.0 & 2 & 0.0 & 0 & -- \\
\hline s & Lovisa & 1987 & 119 & 1 & 0.0 & 41 & 0.0 & 71 & 1.4 & 6 & 0.0 \\
\hline $\mathrm{T}$ & Kotka & 1987 & 30 & 0 & - & 23 & 0.0 & 7 & 0.0 & 0 & - \\
\hline \multirow[t]{2}{*}{$\mathrm{U}$} & Virolahti & $1988 / 89 / 90$ & 490 & 0 & - & 12 & 0.0 & 369 & 0.3 & 109 & 3.7 \\
\hline & Total & & 5983 & 550 & & 1943 & & 2604 & & 886 & \\
\hline
\end{tabular}

Gulf of Bothnia (Table 1). At the other sampling sites in the Gulf of Finland and in the Gulf of Bothnia lower disease prevalences were recorded (Table 1). Affected gonads were not observed in fish taken for comparison from Lake Pyhäjärvi.

\section{Temporal distribution of affected roach}

No large year-to-year fluctuations in disease prevalences were recorded in sampling site $U$ (Table 2). At site $\mathrm{N}$ the highest disease prevalences were recorded during 1990 for length classes $20-25 \mathrm{~cm}, 25-30 \mathrm{~cm}$ and
$>30 \mathrm{~cm}$, with decreasing prevalences during 1994 and 1995. In length class $<20 \mathrm{~cm}$ large fluctuations in disease prevalences occurred.

Affected gonads were observed in roach in spring as well as in autumn.

\section{Length distribution of affected roach}

In the roach population most seriously affected, from site $\mathrm{N}$ in the Archipelago Sea, affected gonads were observed in fish 13 to $39 \mathrm{~cm}$ in length (Fig. 8). Larger (older) fish were more often affected than smaller

Table 2. Rutilus rutilus. Prevalence of roach affected by gonadal impairment in different length classes at 2 sampling sites during different years

\begin{tabular}{|c|c|c|c|c|c|c|c|c|c|c|}
\hline \multirow[t]{2}{*}{ Site } & \multirow[t]{2}{*}{ Year } & \multirow{2}{*}{$\begin{array}{c}\text { Total } \\
\text { no. of } \\
\text { fish } \\
\text { examined }\end{array}$} & \multicolumn{2}{|c|}{$<20 \mathrm{~cm}$} & \multicolumn{2}{|c|}{$20-25 \mathrm{~cm}$} & \multicolumn{2}{|c|}{$25-30 \mathrm{~cm}$} & \multicolumn{2}{|c|}{$>30 \mathrm{~cm}$} \\
\hline & & & $\begin{array}{l}\text { No. of } \\
\text { fish } \\
\text { examined }\end{array}$ & $\begin{array}{c}\text { Disease } \\
\text { prevalence } \\
(\%)\end{array}$ & $\begin{array}{c}\text { No. of } \\
\text { fish } \\
\text { examined }\end{array}$ & $\begin{array}{c}\text { Disease } \\
\text { prevalence } \\
(\%)\end{array}$ & $\begin{array}{c}\text { No. of } \\
\text { fish } \\
\text { examined }\end{array}$ & $\begin{array}{c}\text { Disease } \\
\text { prevalence } \\
(\%)\end{array}$ & $\begin{array}{c}\text { No. of } \\
\text { fish } \\
\text { examined }\end{array}$ & $\begin{array}{c}\text { Disease } \\
\text { prevalence } \\
(\%)\end{array}$ \\
\hline $\mathrm{N}$ & 1988 & 597 & 0 & - & 1 & 0.0 & 259 & 33.2 & 337 & 73.6 \\
\hline $\mathrm{N}$ & 1990 & 212 & 152 & 3.9 & 27 & 29.6 & 16 & 56.3 & 17 & 76.5 \\
\hline$N$ & 1994 & 273 & 58 & 24.1 & 97 & 16.5 & 64 & 46.9 & 54 & 55.6 \\
\hline $\mathrm{N}$ & 1995 & 883 & 73 & 6.8 & 236 & 7.6 & 318 & 40.6 & 256 & 53.9 \\
\hline $\mathrm{N}$ & Total & 1965 & 283 & 9.0 & 361 & 11.6 & 657 & 39.0 & 664 & 65.1 \\
\hline U & 1988 & 147 & 0 & - & 10 & 0.0 & 110 & 0.9 & 27 & 3.7 \\
\hline U & 1989 & 133 & 0 & - & 2 & 0.0 & 109 & 0.0 & 22 & 4.5 \\
\hline $\mathrm{U}$ & 1990 & 210 & 0 & - & 0 & - & 150 & 0.0 & 60 & 3.3 \\
\hline $\mathrm{U}$ & Total & 490 & 0 & - & 12 & 0.0 & 369 & 0.3 & 109 & 3.7 \\
\hline
\end{tabular}


Fig. 8. Rutilus rutilus. Length distribution of healthy (unaffected) roach, roach affected with gonadal impairment (affected), and percentage distribution of affected roach (prevalence) of the appropriate length class. Roach were sampled from site $\mathrm{N}$ during 1988, 1990, 1994 and 1995

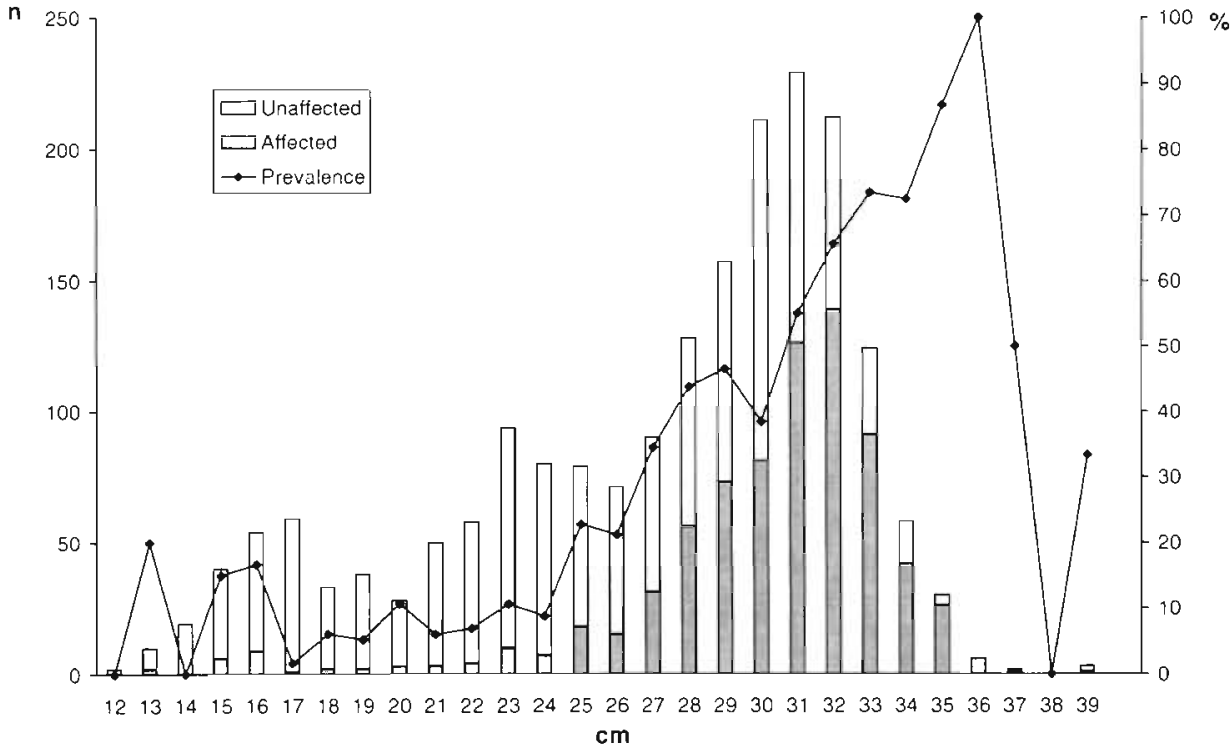

$\mathrm{cm}$ (younger) fish. Of the examined roach of a length from 30 to $36 \mathrm{~cm}$, between 50 and $100 \%$ were affected in the different $1 \mathrm{~cm}$ length classes (Fig. 8). Unfortunately the number of fish in some length classes were rather few, making these results unsure.

\section{DISCUSSION}

The results clearly indicated that roach from the brackish water environment along the Finnish coast were affected by pathological changes in the gonads. The absence of defects in roach from fresh water suggests that there were one or several factors in the northern Baltic Sea contributing to the development of the disease. The presence of Pleistophora mirandellae in most examined affected gonads indicates that this microsporidian parasite was closely associated with the observed pathological changes.

In previous investigations in the northern Baltic Sea Pleistophora mirandellae has been observed in affected ovaries of roach from Simo (sampling site B in the present study) in the northern Gulf of Bothnia (Pulliainen et al. 1992; reported as Plistophora elegans), and in oocytes of roach from the Archipelago Sea and Gulf of Finland (Pekkarinen 1995). Wiklund \& Bylund (1994) observed unidentified microsporidian parasites in affected ovaries of roach from Finnish coastal waters. P. mirandellae (reported as Plistophora elegans) has also been observed in dead white ova of pike and perch from Simo (Pulliainen et al. 1992). In addition, Maurand et al. (1988) reported that oocytes infected with $P$. mirandellae become whitish and opaque. In the present study white and opaque oocytes together with normal (yellow) oocytes were frequently observed in affected ovaries of roach. Furthermore dark red and brown atretic oocytes occurred in heavily affected specimens, where normal oocytes seldom were present.

In other water bodies (mainly fresh water) Pleistophora mirandellae has been described from several other fish species, such as bleak Alburnus alburnus (Vaney \& Conte 1901, Canning \& Lom 1986), dace Leuciscus leuciscus, chub Leuciscus cephalus, gudgeon Gobio gobio and Telestes sofia (Maurand et al. 1988).

Similar gonad anomalies as reported in the present paper have previously been observed in roach from areas influenced by bleached pulp mill effluents (Sandström et al. 1988) and by cooling water from a nuclear power plant (Luksiene \& Sandström 1994). Both areas were located on the east coast of Sweden in the northern Baltic Sea and the anomalies were suggested to be associated with the respective discharges. In histopathological examinations of the ovaries, microsporidian or other infective agents were not reported (Sandström et al. 1988, Luksiene \& Sandström 1994). In this study a high disease prevalence was also observed in a roach sample taken close to the cooling water discharge from the nuclear power plant in Olkiluoto (site L). Unfortunately the number of fish in the sample examined was rather low $(n=20)$ for any firm conclusions to be drawn. On the other hand, there were no industries in the vicinity of the sites in the Archipelago Sea where the disease prevalences were high.

The strong degeneration of large sections rather than individual oocytes of the ovary of the roach suggests that autoinfection might occur. However, if and how this infection is taking place has to be verified experimentally. On the other hand, mature spores released to the lumen were exposed to phagocytosis which could be observed when disrupted oocytes were 
subject to massive invasion of phagocytic cells. Intact oocytes filled with spores were occasionally observed, indicating a depressed cell reaction to the development of the parasite. A similar host-parasite reaction has also been observed for Pleistophora ovariae (Dyková \& Lom 1980).

The frequent appearance of hermaphrodites in the roach population affected with gonad defects was surprising. However, this condition has previously been reported for dace from freshwater in France (Maurand et al. 1988) and roach in Finnish coastal waters (Wiklund \& Bylund 1994, Pekkarinen 1995) in connection with infection with Pleistophora mirandellae (Pekkarinen 1995). Occasional cases of hermaphrodite specimens of roach (Jafri \& Ensor 1979) as well as of other fish species have been described (Blachuta ct al. 1991) although mass occurrence of hermaphrodite roach has not been reported before. A high temperature has been suggested to cause hermaphroditism (Luksiene \& Sandström 1994). However, previous studies (Maurand et al. 1988, Pekkarinen 1995) and the present study suggest that the presence of hermaphrodite roach specimens might be related to microsporidian infection in female ovaries.

In males the parasites did not cause any serious damage to the host testes tissue and the spermatides were not infected with spores. Cysts containing spores occurred mainly in small (young) males, suggesting that the parasite will not accumulate in the fish, a process which obviously is taking place in females. The presence of phagocytes around the cysts suggests that the spores will eventually be ingested and destroyed.

The severity of the disease signs, including serious atresia of oocytes and destruction of whole ovaries, presently observed in roach suggests that the ability of the affected fish to produce viable offspring is seriously reduced. According to local fishermen, however, there is no indication of a reduced roach population even at the most affected sites ( $N$ and $O$ ). Presumably, the young unaffected roach are supporting the population density. In another study, conducted in an area affected with cooling water discharges from a nuclear power plant, a reduced local recruitment of a roach population was suggested to be explained by gonad malfunction in females (Luksiene \& Sandström 1994).

The presence of large (old) roach specimens heavily infected with parasites indicates that the microsporidian infection is probably not lethal to the fish, which has also previously been suggested for other fish species infected with Pleistophora mirandellae (Maurand et al. 1988). The reason why the microsporidian parasites can establish such a heavy infection in roach in some areas is unknown. More detailed investigations are in progress to trace the etiology of this disease.
Acknowledgements. The skillful technical assistance of Inger Böckerman, Staffan Eklow, Mikael Himberg, Henna-Riitta Lehti, Sami Nikoskelainen, Esa Nummelin, Pia Nyman, Barbro Nyström, Tina Oetken, Diana Toivola and Svante Wistbacka is greatly acknowledged. The study was performed in cooperation with the staff from the Finnish Game and Fisheries Research Institute and financed by Abo Akademi University, the Ministry of Agriculture and Forestry, and the Ministry of Environment. Finnish Game and Fisheries Research Institute and Husö Biological Station are acknowledged for providing laboratory facilities

\section{LITERATURE CITED}

Blachuta J, Witkowski A, Kokurewicz B (1991) An hermaphrodite grayling, Thymallus thymallus (L.), from the Nysa Klodzka river (Lower Silesia, Poland). J Fish Biol 38: 955-957

Bylund $G$, Lerche $O$ (1995) Thiamine therapy of $M 74$ affected fry of Atlantic salmon Salmo salar. Bull Eur Ass Fish Pathol 15:93-97

Canning EU, Lom J (1986) The microsporidia of vertebrates. Academic Press, London

Collier TK, Stein JE, Sanborn HR, Hom T, Myers MS, Varanasi U (1992) Field studies of reproductive success and bioindicators of maternal contaminant exposure in English sole (Parophrys vetulus). Sci Total Environ 116:169-185

Dyková I, Lom J (1980) Tissue reactions to microsporidian infections in fish. J Fish Dis 3:265-283

Fisher JP. Spitsbergen JM, Getchell R, Symula J, Skea J, Babenzein $M$. Chiotti $T$ (1995) Reproductive failure of landlocked A.tlantic salmon from New York's Finger Lakes: investigations into the etiology and epidemiology of the 'Cayuga syndrome'. J Aquat Anim Health 7:81-94

Hansen PD, Westernhagen von $\mathrm{H}$, Rosenthal $\mathrm{H}$ (1985) Chlorinated hydrocarbons and hatching success in Baltic herring spring spawners. Mar Environ Res 15:59-76

Hunter JR, Macewicz BJ (1985) Rates of atresia in the ovary of captive and wild northern anchovy, Engraulis mordax. Fish Bull 83:119-136

Jafri SIH (1990) Gametogenesis in roach, Rutilus rutilus (L.) (Cyprinidae: Teleostei). Pakistan J Zool 22:361-377

Jafri SIH, Ensor DM (1979) Occurrence of an intersex condition in the roach Rutilus rutilus (L). J Fish Biol 15:547-549

Johnson LL, Stein JE, Collier TK, Casillas E, Varanasi U (1994) Indicators of reproductive development in prespawning female winter flounder (Pleuronectes americanus) from urban and non-urban estuaries in the northeast United States. Sci Total Environ 141:241-260

Karås P, Neuman E, Sandström O (1991) Effects of a pulp mill effluent on the population dynamics of perch, Perca fluviatilis. Can J Fish Aquat Sci 48:28-34

Larsson PO (1994) Recent development of the cod stocks around Sweden and possible reproduction disturbances. In: Norrgren L (ed) Report from the Uppsala workshop on reproduction disturbances in fish, 20-22 October 1993. Swedish Environmental Protection Agency, Report 4346, Solna, p 26-34

Longwell AC, Chang S, Hebert A, Hughes JB, Perry D (1992) Pollution and developmental abnormalities of Atlantic fishes. Environ Biol Fish 35:1-21

Luksiene D, Sandström O (1994) Reproductive disturbance in a roach (Rutilus rutilus) population affected by cooling water discharge. J Fish Biol 45:613-625

Maurand J, Loubes C, Gasc C, Pelletier J, Barral J (1988) Pleistophora mirandellae Vaney \& Conte, 1901, a micro- 
sporidian parasite in cyprinid fish of rivers in Hérault: taxonomy and histopathology. J Fish Dis 11:251-258

Norrgren L, Andersson T, Bergqvist PA, Björklund I (1993) Chemical, physiological and morphological studies of feral Baltic salmon (Salmo salar) suffering from abnormal fry mortality. Environ Toxicol Chem 12:2065-2075

Norrgren L, Bengtsson BE, Börjeson H (1994) Summary of the workshop 'Reproduction Disturbances in Fish' In: Norrgren $\mathrm{L}$ (ed) Report from the Uppsala workshop on reproduction disturbances in Fish, 20-22 October 1993. Swedish Environmental Protection Agency, Report 4346, Solna, p 7-11

Pedersen B.H (1993) Embryos and yolk-sac larvae of turbot Scophthalmus maximus are infested with an endoparasite from the gastrula stage onwards. Dis Aquat Org 17:57-59

Pedersen BH, Buchmann K, Køie M (1993) Baltic larval cod Gadus morhua are infested with a protistan endoparasite in the yolk sac. Dis Aquat Org 16:29-33

Pekkarinen M (1995) Pleistophora mirandellae Vaney \& Conte, 1901 (Protozoa: Microspora) infection in the ovary of the roach, Rutilus rutilus (L.), from Finnish coastal waters. Memoranda SFFF (Soc Fauna Flora Fenn) 71. $19-32$

Pulliainen E, Korhonen K, Kankaanranta L, Mäki K (1992) Non-spawning burbot on the northern coast of the Bothnian Bay. Ambio 21:170-175

Sandström O, Neuman E, Karås P (1988) Effects of a bleached

Responsible Subject Editor: W. Körting, Hannover, Germany pulp mill effluent on growth and gonad function in Baltic coastal fish. Wat Sci Technol 20:107-118

Segerstrảle C (1945) Leker laken (Lota vulgaris) i Finlands kustvatten med intervaller såsom laxfisk? Memoranda SFFF (Soc Fauna Flora Fenn) 3:74-76

Spies RB, Rice DW Jr (1988) Effects of organic contaminants on reproduction of the starry flounder Platichthys stellatus in San Francisco Bay. Mar Biol 98:191-200

Vaney C, Conte A (1901) Sur une nouvelle microsporidie, Pleistophora marandellae, parasite de l'ovaire d'Alburnus mirandella Blanch. C R Acad Sci 133:644-646

Westernhagen von $\mathrm{H}$, Cameron P, Dethlefsen $\mathrm{V}$, Janssen $\mathrm{D}$ (1989) Chlorinated hydrocarbons in North Sea whiting (Merlangius merlangus L.), and effects on reproduction. I. Tissue burden and hatching success. Helgol Meeresunters 43:45-60

Westernhagen von $\mathrm{H}$, Dethlefsen V, Cameron P, Berg J, Furstenberg G (1988) Developmental defects in pelagic fish embryos from the western Baltic. Helgol Meeresunters 42:13-36

Westernhagen von $H$, Rosenthal $H$, Dethlefsen V, Ernst W, Harms U, Hansen PD (1981) Bioaccumulating substances and reproductive success in Baltic flounder Platichthys flesus. Aquat Toxicol 1:85-99

Wiklund T, Bylund G (1994) Reproductive disorder in roach [Rutilus rutilus] in the northern Baltic Sea. Bull Eur Ass Fish Pathol 14:159-162

Manuscript first received: December 4, 1995 Revised version accepted: April 10, 1996 